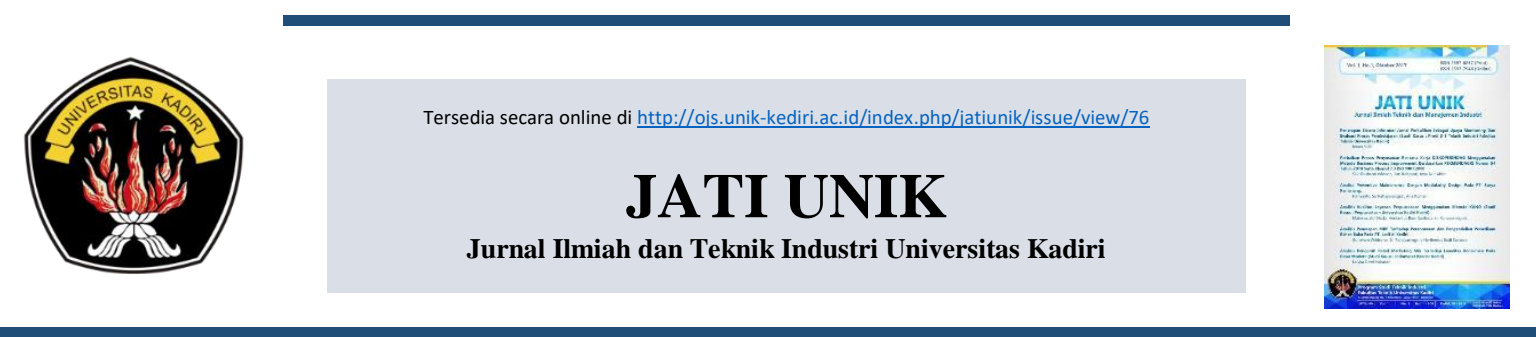

\title{
Pengaruh Karakteristik Wirausahawan Design Grafis Terhadap Tingkat Keberhasilan Usaha
}

\author{
Afiff Yudha Tripariyanto*1, Ana Komari ${ }^{2}$, Heribertus Budi Santoso ${ }^{3}$ \\ 1,2,3Program StudiTeknik Industri, FakultasTeknik, Universitas Kadiri \\ Email: afiff@unik-kediri.ac.id ${ }^{1}$, ana@ unik-kediri.ac.id ${ }^{2}$, heribertus@unik-kediri.ac.id ${ }^{3}$
}

I nformas $\boldsymbol{i}$ A r tike l
Riwayat Artikel :
Received : 30 - Septermber - 2019
Revised : 6 - Oktober - 2019
Accepted : 27 - Oktober - 2019

Kata kunci :

Graphic Design

Multiple Linear Regressions

T-Test

F-Test

\begin{abstract}
$\boldsymbol{A} \boldsymbol{b} \boldsymbol{s} \boldsymbol{t} \boldsymbol{r} \boldsymbol{a} \boldsymbol{c t}$
The rapid development of graphic design raises many people who want to become graphic design entrepreneurs. In this study aims to determine the effect of the characteristics of graphic design entrepreneurs on the level of business success. Used 8 independent variables, namely hard work, cooperation, appearance, confidence, good at making decisions, want to increase knowledge, ambition to move forward and good at communicating to the level of business success. The sample used was of the saturated sample because the respondents were less than 100 people, as many as 40 respondents. The method used is multiple linear regressions. The results of the study are in the partial test, the independent variable that is not able to influence the level of success of graphic design business is a good performance variable, confident of pioneered business, want to increase knowledge, ambition to move forward, while in the simultaneous test the characteristics of entrepreneurial design are not influence the success of the business. In the multiple linear regression test models are obtained namely: $Y=4,140+0,957 X_{1}+0,904 X_{2}-$ $0,149 X_{3}-0,071 X_{4}+0.029 X_{5}+-1,070 X_{6}-0,914 X_{7}+0,257 X_{8}$
\end{abstract}

Untuk melakukan sitasi pada penelitian ini dengan format :

A. P. Musmuliadi, "Pengaruh Media Desain Grafis Berbasis Adobe," J. Teknol. Pendidik., vol. 3, no. April, 2018.

\begin{abstract}
A b s trak
Perkembangan desain grafis yang pesat menimbulkan banyak orang yang ingin menjadi pengusaha desain grafis.Pada penelitian ini bertujuan untuk mengetahui pengaruh karakteristik wirausahawan desain grafis terhadap tingkat keberhasilan usaha. Digunakan 8 variabel bebas yaitu kerja keras, kerja sama, penampilan, yakin, pandai membuat keputusan, mau menambah pengetahuan, ambisi untuk maju dan pandai berkomunikasi terhadap tingkat keberhasilan usaha. Sampel yang digunakan berjenis sampel jenuh karena responden kurang dari 100 orang, yaitu sebanyak 40 responden. Metode yang digunakan adalah regres linier berganda. Hasil dari penelitian yaitu pada uji T, variabel bebas yang tidak mampu memberikan pengaruh terhadap tingkat keberhasilan usaha desain grafis adalah variabel penampilan yang baik, yakin akan usaha yang dirintis, mau menambah pengetahuan, ambisi untuk maju, sedangkan pada uji
\end{abstract}


F wirausaha desain grafis tidak memberikan pengaruh terhadap keberhasilan usaha. Pada uji regreli linier berganda didapatkan model yaitu : $\quad \mathrm{Y}=4,140+0,957 \mathrm{X}_{1}+0,904 \mathrm{X}_{2}-0,149 \mathrm{X}_{3^{-}}$ $0,071 \mathrm{X}_{4}+0,029 \mathrm{X}_{5}+-1,070 \mathrm{X}_{6}-0,914 \mathrm{X}_{7}+0,257 \mathrm{X}_{8}$.

\section{Pendahuluan}

Henry Cole berperan penting dalam memperkenalkan pendidikan desain di Inggris. Dalam sebuah journal berjudul Journal of Design and Manufactures, ia memberitahu pemerintah akan pentingnya desain grafis dalam sebuah jurnal [1]. Desain grafis adalah kombinasi kompleks katakata dan gambar, angka-angka dan grafik, foto-foto dan ilustrasi yang membutuhkan pemikiran khusus dari seorang individu yang bisa menggabungkan elemen-eleman ini, sehingga mereka dapat menghasilkan sesuatu yang khusus, sangat berguna, mengejutkan atau subversif atau sesuatu yang mudah diingat [2], [3] [4],[5],[6], [7]. Design grafis adalah bagaimana membangun riset kedalam konsep design menggunakan cara kerja yang benar mempuyai nilai estetika,keselarasan,kreatif dan inovatif serat tepat waktu sehingga konsumen sangat bisa menerima hasil dari design kita dengan senang hati dan akan kembali lagi dengan konsep pesanan yang berbeda [8],[9]. Berdasarkan latar belakang di atas diketahui karakteristik kewirausahaan merupakan faktor penting dalam keberhasilan wirausaha yang bergerak pada Design Grafis [10], [11], [12].

Definisi seorang Wirausaha adalah seseorang yang bebas dan memiliki kemampuan untuk hidup mandiridalam menjalankan kegiatan usaha atau bisnisnya. Ia bebas merancang, menentukan, mengelola, atau mengendalikan semua usahanya.[13]. Sedangkan kewirausahaan adalah suatu sikap, jiwa dan kemampuan untuk menciptakan sesuatu yang baru yang sangat bernilai dan berguna bagi dirinya dan orang lain [13]. Kewirausahaan merupakan sikap mental dan jiwa yang selalu aktif atau kreatif berkarya, bercipta, berkarsa dan bersahaja dalam berusaha untuk meningkatkan pendapatan pada usahanya. Wirausaha adalah orang yang terampil dalam memanfaatkan peluang dalam mengembangkan usahanya dengan tujuan untuk meningkatkan kehidupannya. Salah satu bentuk peluang yang dapat dimanfaatkan adalah wirausaha dibidang desain grafis [14], [15], [16].

Dalam perkembangan desain ini,dimanfaatkan peneliti untuk melakukan penelitian yaitu pada tingkat keberhasilan wirasausaha desain grafis terhadap tingkat keberhasilan berwirausaha. Dalam hal ini digunakan ada beberapa faktor yang perlu diperhatikan [17], [18]yaitu sebagai berikut :

1. Kerja Keras Kerja keras merupakan modal keberhasilan seorang wirausaha. Setiap pemgusaha yang sukses menempuh kerja keras dan sungguh-sungguh dalam usahanya.

2. Kerja Sama dengan Orang Lain Kerjasama dapat diwujudkan dalam lingkungan pergaulan. Hal ini merupakan langkah pertama untuk mengembangkan usaha. Wirausahawan harus murah hati, mudah bergaul, ramah, disenangi masyarakat, dan menghindari perbuatan yang merugikan orang lain.

3. Penampilan yang Baik Penampilan ditekankan dalam berwirausaha. Penampilan yang diharapkan adalah penampilan perilaku yang jujur dan didiplin. 
4. Yakin Seorang wirausaha harus dapat yakin kepada diri sendiri. Keyakinan yang harus dimiliki adalah untuk maju dan dilandasi ketekunan serta kesabaran.

5. Pandai Membuat Keputusan Wirausahawan harus dapat membuat keputusan jika dihadapkan pada alternatif yang sulit. Cara memberikan keputusan dengan pertimbangan matang dan jangan ragu-ragu dalam mengambil keputusan

6. Mau Menambah Pengetahuan Dengan menambah ilmu pengetahuan terutama dalam bidang usaha, diharapakan wirausahawan dapat mendukung kemampuan dan kemajuan dalam usaha.

7. Ambisi untuk Maju Tanpa ambisi yang kuat wirausahawan tidak akan mencapai keberhasilan. Ambisi kuat harus diimbangi dengan usaha yang keras dan disiplin diri yang baik.

8. Pandai Berkomunikasi Wirausahawan harus dapat menarik orang lain dengan tutur kata yang baik, sopan, jujur, dan percaya diri. Sehingga akan memberi kesan kepada orang lain menjadi tertarik dan orang akan percayadengan apa yang disampaikan

\section{Tinjauan Pustaka}

\subsection{Desain Grafis}

Pengertian desain adalah sebuah hasil akhir dari rangkaian proses kreatif seseorang (http://niappa.wordpress.com). Namun menurut [19], desain grafis didefinisikan sebagai aplikasi dari keterampilan seni dan komunikasi untuk kebutuhan bisnis dan industri. Aplikasi ini dapat meliputi periklanan dan penjualan produk, menciptakan identitas visual untuk institusi, produk, dan perusahaan, dan lingkungan grafis, desain informasi, dan secara visual menyempurnakan pesan dalam publikasi (http://slametriyanto.net).

\subsection{Wirausahawan}

Wirausaha adalah orang yang menciptakan kesejahteraan untuk orang lain, menemukan cara-cara baru untuk menggunakan sumber daya, mengurangi pemborosan, dan membuka lapangan kerja yang disenangi[20]. Prawirokusumo juga berpendapat bahwa seorang wirausaha adalah mereka yang melakukan usaha-usaha kreatif dan inovatif dengan jalan mengembangkan ide dan meramu sumber daya untuk menemukan peluang dan perbaikan hidup. Banyak ahli menjabarkan karakteristik kewirausahaan dengan konsep yang berbedabeda. Meredith mengemukakan karakteristik dan watak seorang wirausahawan antara lain sebagai berikut[20]:

- Percaya diri dan optimis, memiliki watak kepercayaan diri yang kuat, ketergantungan terhadap orang lain, dan bersikap individual.

- Berorientasi pada tugas dan hasil, memiliki kebutuhan untuk berprestasi, berorientasi pada keuntungan finansial, mempunyai motivasi yang kuat, energik, tekun, tabah, memilliki tekad untuk bekerja keras, dan inisiatifnya tinggi.

- Berani mengambil risiko dan menyukai tantangan, dan mampu mengambil risiko yang wajar.

- Memiliki jiwa kepemimpinan, mudah beradaptasi dengan orang lain, dan terbuka terhadap saran dan kritik dari orang lain.

- Orisinalitas tinggi, memiliki watak inovatif, kreatif, dan fleksibel. 
- Berorientasi, memiliki visi dan perspektif terhadap masa depan

\section{Metode Penelitian}

Dalam mempermudah ilustrasi pada penelitian ini digunakan kerangka berpikir sebagai berikut :

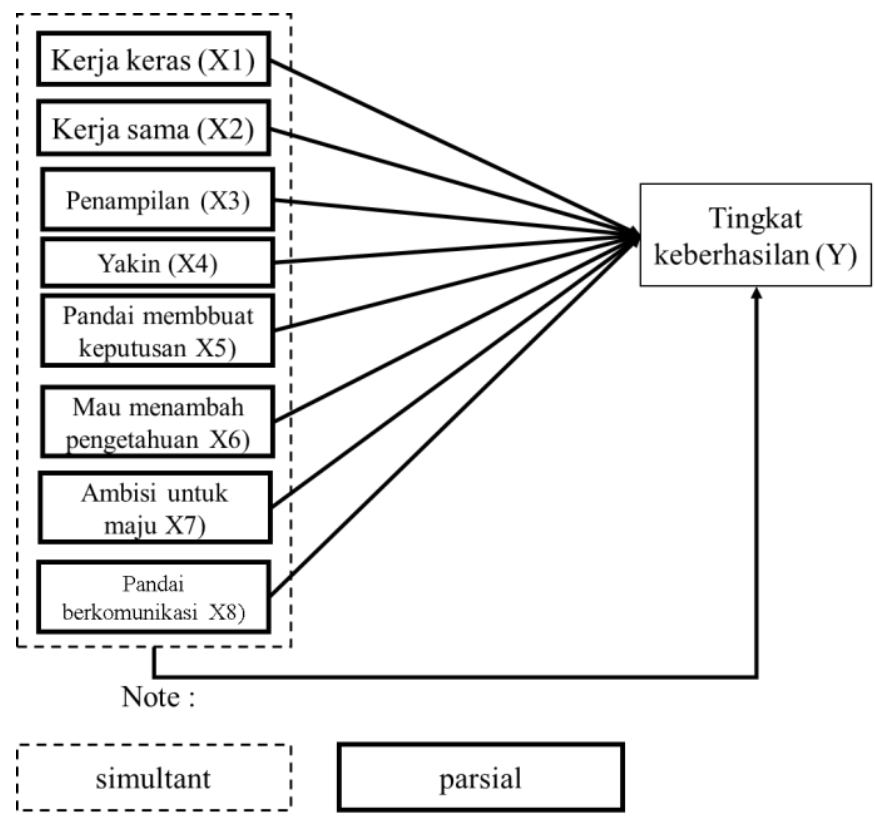

Gambar 1 Kerangka berpikir

\subsection{Populasi dan Sampel Penelitian}

Populasi pada penelitian ini menggunakan populasi yaitu pemilik usaha desain grafis yang berada di Kota Kediri dengan total 40 responden [21],[22],[23]. Terkait jumlah responden kurang dari 100 responden, maka populasi dijadikan untuk sampel penelitian pada tahun 2019.

\subsection{Variabel Penelitian dan Cara Pengukuran}

Tabel 1 Variabel penelitian dan cara pengukuran

\begin{tabular}{|c|c|c|c|}
\hline Variabel Penelitian & Pernyataan & $\begin{array}{c}\text { Cara } \\
\text { Pengukuran }\end{array}$ & Skala \\
\hline $\mathrm{X} 1$ & Kerja keras & \multirow[t]{8}{*}{ Skala likert } & \multirow{8}{*}{$\begin{array}{l}1 \text { = Tidak mampu } \\
2 \text { =kurang } \\
\text { mampu } \\
3 \text { =cukup mampu } \\
4 \text { =lebih mampu } \\
5=\text { sangat mampu }\end{array}$} \\
\hline $\mathrm{X} 2$ & Kerja sama & & \\
\hline $\mathrm{X} 3$ & Penampilan & & \\
\hline $\mathrm{X} 4$ & Yakin & & \\
\hline $\mathrm{X} 5$ & Pandai membuat keputusan & & \\
\hline X6 & Mau menambah pengetahuan & & \\
\hline $\mathrm{X} 7$ & Ambisi untuk maju & & \\
\hline $\mathrm{X} 8$ & Pandai berkomunikasi & & \\
\hline
\end{tabular}


Dalam melakukan pengumpulan data penelitian, dilakukan kegiatan penyebaran kuisioner. Penyebaran kuisioner dilakukan pengambilan data secara langsung tanpa melakukan rekayasa terhadap data yang diperoleh dari responden [24], [25]. Kuisioner disebarkan kepada responden untuk mengetahui Pengaruh Karakteristik Wirausahawan Design Grafis Terhadap Tingkat Keberhasilan Usaha di Kota Kediri tahun 2019.

\subsection{Metode Analisis Data}

\section{a) Uji Validitas}

Uji validitas digunakan untuk mengetahui apakah data yang didapat dari pengisian kuisioner memiliki tingkat kevalidan yang dapat digunakan untuk uji selanjutnya. Cara melakukan uji validitas dapat menggunakan korelasi bivariate pearson dan correlated item - total correlation yang didapatkan analyze menggunakan software SPSS IBM Version 23.0 [26], [27],[28]. Pengambilan keputusan interpretasi data dalam uji validiats sebagai berikut :

- Nilai $\mathrm{R}_{\text {hitung }}>\mathrm{R}_{\text {tabel }}$, maka item - item pertanyaan dalam kuisioner dinyatakan signifikan berkorelasi terhadap skor total dinyatakan valid.

- Nilai $\mathrm{R}_{\text {hitung }}<\mathrm{R}_{\text {tabel }}$, maka item - item pertanyaan dalam kuisioner dinyatakan tidak signifikan berkorelasi terhadap skor total dinyatakan tidak valid.

\section{b) Uji Reliabilitas}

Menurut [29] untuk mengetahui kereliabelan dari sebuah data - data yang diuji, dilihat pada hasil perhitungan nilai cronbach's alpha $(\alpha)>0,60$ maka variabel dinyatakan reliabel [30]. Jika perhitungan pada nilai cronbach's alpha $(\alpha)<0,60$ maka variabel dinyatakan tidak reliabel.

c) Uji Asumsi Klasik

Didalam Penggunaan uji asumsi klasik memiliki lima asumsi yang digunakan sebagai model yang harus dipenuhi estimasi linier terbaik. Asumsi klasik antara lain yaitu [31], [27] :

- Uji Normalitas

Menilai sebaran data pada sebuah kelompok data atau variabel, apakah sebaran data tersebut berdistribusi normal ataukah tidak.

- Uji Autokorelasi

Asumsi autokorelasi terjadi pada sebuah model prediksi, maka nilai disturbance tidak lagi berpasangan secara bebas, melainkan berpasangan secara autokorelasi.

- Uji Multikolinieritas

Uji multikolinearitas untuk memberikan kepastian apakah di dalam sebuah model regresi ada hubungan atau tidak antar variabel bebas. Interkorelasi itu dapat dilihat dengan nilai koefisien korelasi antara variabel bebas, nilai VIF dan Tolerance, nilai Eigenvalue dan Condition Index, serta nilai standar error koefisien beta atau koefisien regresi parsial pada software SPSS ynag sudah dilakukan analisis Uji asumsi klasik. 
- Uji Heteoskedastisitas

Heteroskedastisitas adalah yaitu keadaan dimana terjadinya ketidaksamaan varian dari error untuk semua pengamatan setiap variabel bebas pada model regresi..

- Uji Linieritas

Uji ini biasanya digunakan sebagai prasyarat dalam analisis korelasi atau regresi linear. Pengujian pada software IBM SPSS Version 23.0 dengan menggunakan Test for Linearity dengan pada taraf signifikansi 0.05. Dua variabel dikatakan mempunyai hubungan yang linear bila signifikansi (Linearity) kurang dari 0,05.

\section{d) Regresi Linier Berganda}

Model persamaan regresi pada penelitian ini [27], yaitu :

Keterangan :

$$
Y=a+b_{k} X_{k}+\ldots+b_{k} X_{k}
$$

Y : nilai prediksi dari Y

a : nilai konstan

$b_{k} \quad$ : variabel bebas

$\mathrm{X}_{\mathrm{k}} \quad$ : variabel independen

\section{e) Uji T}

Untuk mengetahui signifikansi pengaruh variabel bebas terhadap variabel terikat secara parsial. Dengan membandingkan antara nilai $t$ hitung dengan nilai $t$ tabel, maka dapat ditentukan apakah Ho ditolak atau diterima.

\section{f) $\mathbf{U j i} \mathbf{F}$}

Uji F digunakan untuk mengetahui signifikansi pengaruh variabel bebas terhadap variabel terikat secara bersama-sama. Dengan membandingkan antara nilai $F_{\text {hitung }}$ dengan nilai $F_{t a b e l}$, maka dapat ditentukan apakah terjadi penolakan atau penerimaan hipotesis yang sudah diduga.

\section{Hasil dan Pembahasan}

Didalam pengolahan data uji validitas, didapatkan hasil valid dengan total variabel independen sejumlah 8 variabel independen. Pada variabel independen memiliki $R_{\text {hitung }}>R_{\text {tabel }}$.

Tabel 2 Uji validitas

\begin{tabular}{|c|c|c|c|c|}
\hline \multicolumn{2}{|c|}{ Pernyataan } & $\mathrm{R}_{\text {hitung }}$ & $\mathrm{R}_{\text {tabel }}$ & Keterangan \\
\hline X1 & Kerja keras & $.489^{* *}$ & .304 & Valid \\
\hline X2 & Kerja sama & $.570^{* *}$ & .304 & Valid \\
\hline X3 & Penampilan & $.705^{* *}$ & .304 & Valid \\
\hline X4 & Yakin & $.561^{* *}$ & .304 & Valid \\
\hline X5 & Pandai membuat keputusan & $.569^{* *}$ & .304 & Valid \\
\hline
\end{tabular}




\begin{tabular}{|l|c|c|c|c|}
\hline X6 & Mau menambah pengetahuan & $.530^{* *}$ & .304 & Valid \\
\hline X7 & Ambisi untuk maju & $.575^{* *}$ & .304 & Valid \\
\hline X8 & Pandai berkomunikasi & $.573^{* *}$ & .304 & Valid \\
\hline **. Correlation is significant at the 0.01 level (2-tailed). \\
\hline *. Correlation is significant at the 0.05 level (2-tailed). \\
\hline
\end{tabular}

Pada variabel X1 (kerja keras) memiliki nilai Rhitung sebesar 0,489 > 0,304. Pada variabel lainnya tersaji pada tabel 2. Pada perhitungan uji validitas, memiliki korelasi yang signifikan pvalue mencapai 0,01 level (2-tailed).

Tabel 3 Uji Reliabilitas X terhadap Y

\begin{tabular}{|r|r|}
\hline $\begin{array}{c}\text { Cronbach's } \\
\text { Alpha }\end{array}$ & N of Items \\
\hline .734 & 9 \\
\hline
\end{tabular}

Untuk uji reliabilitas memiliki nilai Cronbach Alpha sebesar 0,734.Pada nilai tersebut diartikan data yang diolah adalah reliabel. Nilai cronbach Alpha sebesar 0,734 memiliki kategori bahwa reliabilitas mencukupi.

Tabel 4 Hasil pernyataan rata - rata responden

\begin{tabular}{|l|r|r|r|}
\hline & Mean & \multicolumn{1}{|c|}{$\begin{array}{c}\text { Std. } \\
\text { Deviation }\end{array}$} & N \\
\hline $\mathrm{Y}$ & 3.75 & .742 & 40 \\
\hline $\mathrm{X} 1$ & 3.98 & .620 & 40 \\
\hline $\mathrm{X} 2$ & 3.88 & .686 & 40 \\
\hline $\mathrm{X} 3$ & 3.98 & .698 & 40 \\
\hline $\mathrm{X} 4$ & 4.03 & .423 & 40 \\
\hline $\mathrm{X} 5$ & 3.78 & .768 & 40 \\
\hline $\mathrm{X} 6$ & 4.03 & .577 & 40 \\
\hline $\mathrm{X} 7$ & 3.93 & .730 & 40 \\
\hline $\mathrm{X} 8$ & 3.75 & .707 & 40 \\
\hline
\end{tabular}

Pada rekapitulasi pernyataan dari responden yang berjumlah 40 orang memiliki rata - rata jawaban dengan kisaran mean mulai dari 3,94 sampai dengan 4,03. Dari pernyataan tersebut, jawaban rata - rata adalah cukup mampu sampai lebih mampu karena skala likert menunjukan 3 = cukup mampu dan 4 = lebih mampu. Dalam penelitian ini, wirausahawan dalam bidang desain grafis mampu mewujudkan tingkat keberhasilan usahanya. 
Tabel 5 Nilai korelasi

\begin{tabular}{|c|c|c|c|c|c|c|c|c|c|}
\hline \multirow[b]{2}{*}{ Model } & \multirow[b]{2}{*}{$\mathrm{R}$} & \multirow[b]{2}{*}{$\begin{array}{c}\text { R } \\
\text { Square }\end{array}$} & \multirow[b]{2}{*}{$\begin{array}{l}\text { Adjusted } \\
\text { R Square }\end{array}$} & \multirow[b]{2}{*}{$\begin{array}{l}\text { Std. Error of } \\
\text { the Estimate }\end{array}$} & \multicolumn{5}{|c|}{ Change Statistics } \\
\hline & & & & & $\begin{array}{c}\text { R Square } \\
\text { Change }\end{array}$ & $\begin{array}{c}\text { F } \\
\text { Chang } \\
\mathrm{e}\end{array}$ & $\begin{array}{c}\mathrm{df} \\
1\end{array}$ & $\mathrm{df} 2$ & $\begin{array}{c}\text { Sig. F } \\
\text { Change }\end{array}$ \\
\hline 1 & $.543^{\mathrm{a}}$ & .295 & .113 & .699 & .295 & 1.619 & 8 & 31 & .160 \\
\hline
\end{tabular}

Pada nilai korelasi didalam tabel R Square menunjukkan nilai sebesar 0,295. Nilai tersebut adalah Pengaruh Karakteristik Wirausahawan Design Grafis (X) Terhadap Tingkat Keberhasilan Usaha (Y) adalah sebesar 29,5\%. Sedangkan sisanya yaitu $100 \%-29,5 \%=70,5 \%$ tingkat keberhasilan usaha desain grafis dipengaruhi oleh variabel lain yang tidak diteliti. Pada output $\mathrm{F}$ adalah Uji F. Dalam uji F didapatkan nilai sebesar 1,619. Pada $F_{\text {tabel }}$ didapatkan nilai sebesar 2,18. Maka, variabel tersebut belum dapat memberi pengaruh terhadap tingkat keberhasilan wirausaha.

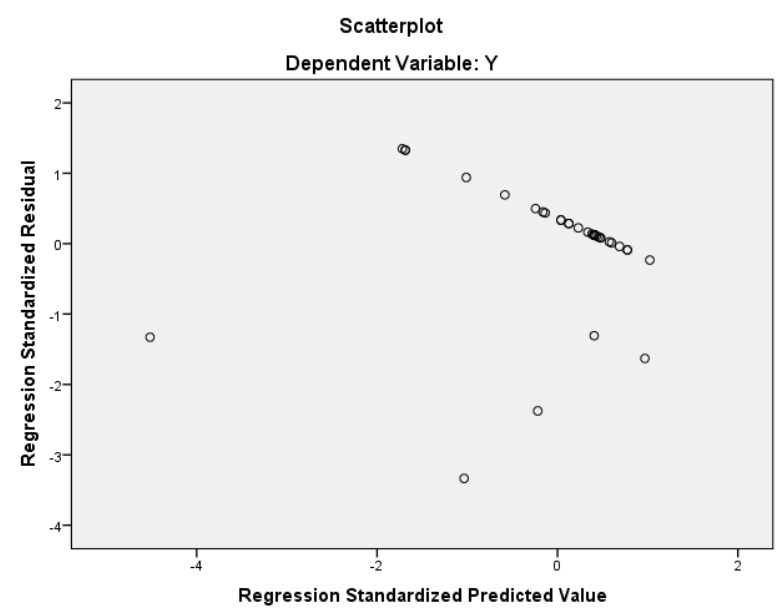

Gambar 2 Scatterplot

Pada hasil output scatterplot, titik - titik yang menyebar diatas sumbu Y dan tidak memiliki pola teratur disimpulkan variabel tidak mengalami heterokedastisitas.Sedangkan pada variabel tersebut, ada titik - titik yang membentuk pola tertentu, hal tersebut dinamakan data bersifat homokedastisitas.

Tabel 6 Koefisien

\begin{tabular}{|l|c|c|c|c|c|}
\hline & Unstandardi & Standar & & & \\
dized & & & \\
zed & Coeffic & & & Collinearity \\
Model & Coefficients & ients & $\mathrm{t}$ & Sig. & Statistics \\
\hline
\end{tabular}




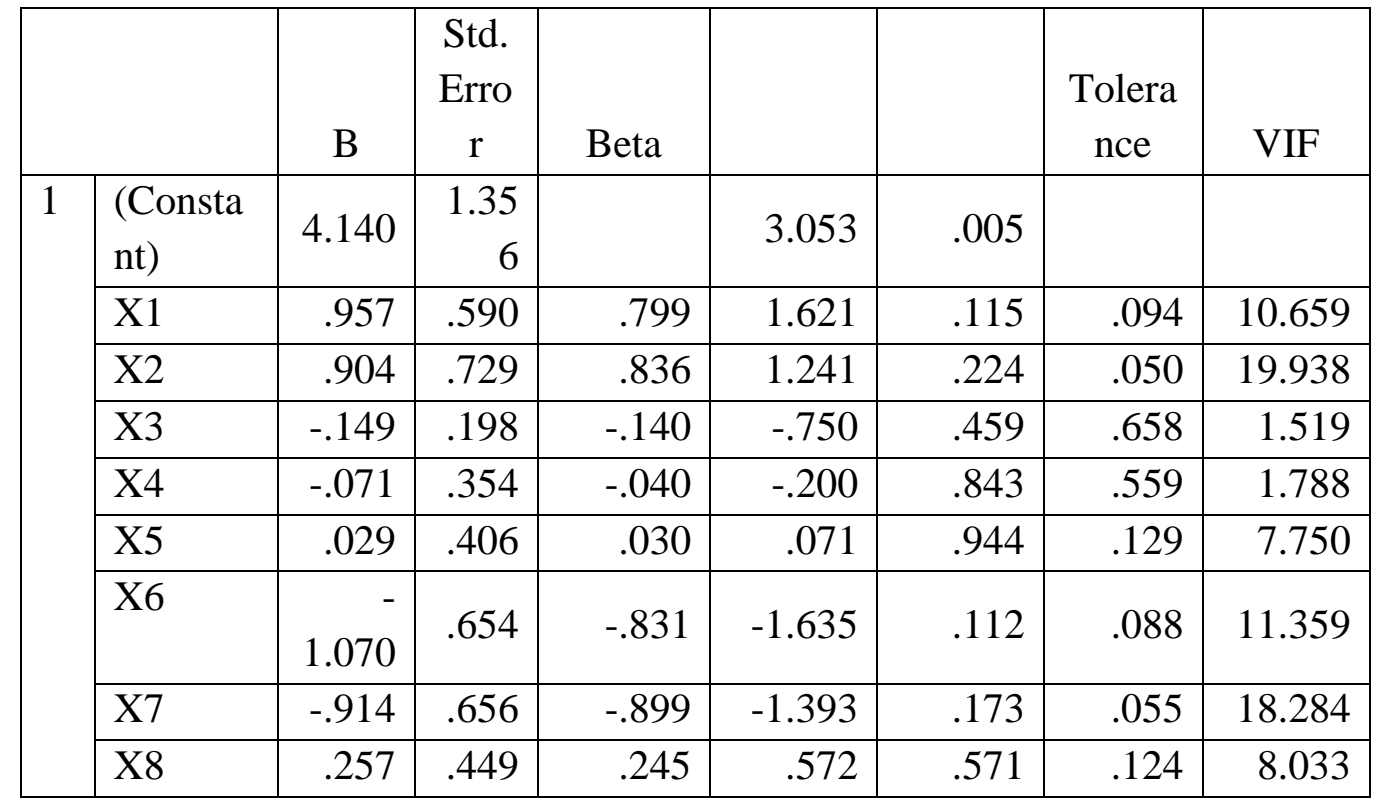

Pada Collinearity Statistics, nilai toleransi alpha adalah 0,05 yang digunakan dalam penelitian ini. Pada nilai Variance Inflation Factor (VIF) seharusnya adalah 5\%, dikarenakan toleransi alpha yang digunakan adalah 0,05. Hasil perhitungan pada output Variance Inflation Factor (VIF) dari masing - masing variabel antara 1,519 sampai tersebar yaitu 19,938. Maka, nilai Variance Inflation Factor (VIF) > 5, dinyatakan terjadi multikolinieritas pada variabel indenpenden. Sedangkan pada variabel independen yang memiliki nilai Variance Inflation Factor (VIF) $<5$ diasumsikan tidak terjadi multikolinieritas. Didalam tabel Unstandardized Coefficients pada sub B memiliki nilai konstan sebesar 4.140. Angak tersebut dapat diartikan bahwa jika semua variabel $\mathrm{X}$ tidak ada aktivitas maka nilai konsisten dari tingkat keberhasilan wirausaha desain grafis (Y) sebesar 4.140. Sedangkan pada variabel X1 yaitu kerja keras alam mewujudkan keberhasilan usaha memiliki nilai sebesar 0,957. Nilai tersebut adalah jika terjadi aktivitas $1 \%$ pada variabel kerja (X1), maka tingkat keberhasilan berwirausaha (Y) akan meningkat 0,957 . Pada variabel X2 yaitu kerja sama akan meningkat sebesar 0,904 jika terjadi aktivitas $1 \%$. Berbeda dengan variabel (X3, X4, X6 dan X7) memiliki nilai negatif, maka setiap terjadi aktivitas $1 \%$ variabel tersebut akan memberi pengaruh negatif pada masing - masing variabel yaitu X3 sebesar -0,149, X4 sebesar -0,071, X6 sebesar -1,070. Pada variabel X5 jika terjadi aktivitas sebesar $1 \%$ akan mengalami peningkatan keberhasilan wirausaha sebesar 0,029 dan pada X8 akan mengalami peningkatan keberhasilan sebesar 0,257. Dari uraian pembahasan tersebut diberikan model regresi sebagai berikut :

$\mathrm{Y}=4,140+0,957 \mathrm{X}_{1}+0,904 \mathrm{X}_{2}-0,149 \mathrm{X}_{3}-0,071 \mathrm{X}_{4}+0,029 \mathrm{X}_{5}+-1,070 \mathrm{X}_{6}-0,914 \mathrm{X}_{7}+0,257 \mathrm{X}_{8}$

Pada uji T didapatkan hasil bahwa variabel X3, X4, X6 dan X7 bernilai negatif yang artinya variabel tidak mampu bekerja sendiri dalam melakukan tingkat keberhasilan wirausaha desain grafis, sedangkan pada variabel X1, X2, X5, X8 mampu bekerja dalam melakukan tingkat keberhasilan wirausaha desain dengan nilai masing - masing pada X1 sebesar 0,957, X2 sebesar 0,904, X5 sebesar 0,029 dan X8 sebesar 0,257. 


\section{Kesimpulan}

Berdasarkan penelitian yang sudah dilakukan pengolahan dan pembahasan, dapat disimpulkan bahwa hasil identifikasi terdapat 10 (sepuluh) komponen (parameter) pada area gas cleaning system dan didapatkan 11 (sebelas) risiko penyimpangan yang bisa terjadi. Nilai risiko dengan perincian untuk level risiko extreme sebanyak 1 (satu) penyimpangan atau sebesar 9\%, level risiko high risk sebanyak 2 (dua) penyimpangan atau sebesar $18 \%$, level risiko moderate sebanyak 6 (enam) penyimpangan atau sebesar 55\% dan level risiko low risk sebanyak 2 (dua) penyimpangan atau sebesar $18 \%$. Pada nilai extreme risk didapatkan pada komponen lower discharge valve of dust bin 1 dan 2 dengan deviation part of functionability. Rekomendasi untuk pencegahan dan penanganan deviation part of functionability yang diakibatkan oleh kegagalan pengoperasian bisa dilakukan dengan cara perawatan secara periodik, memperbaiki hose hidrolik yang rusak dan jika memungkinkan dilakukan penggantian gasket serta pemasangan ulang valve untuk mendapatkan posisi ketegangan hose yang baik.

\section{Daftar Pustaka}

[1] Yorkshirepost, "Henry Cole - Tales of life lived at full throttle by rebel without a cause," https://www.yorkshirepost.co.uk/, 2018.

[2] G. Hatcher et al., "Using linkography to compare creative methods for group ideation," Des. Stud., vol. 58, pp. 127-152, 2018, doi: 10.1016/j.destud.2018.05.002.

[3] P. Lloyd, "You make it and you try it out: Seeds of design discipline futures," Des. Stud., vol. 65, pp. 167-181, 2019, doi: 10.1016/j.destud.2019.10.008.

[4] Madamearchitect, "Visual Thinking: Jessica Helfand on Invention, the Studio as Sanctuary, and Being a Collector," madamaarchitect.org, 2019.

[5] A. Maulina, "Pembelajaran Desain Grafis Pada Mata Pelajaran Multimedia Di Smk Negeri 02 Adiwerna Tegal," Eduarts J. Vis. Arts, vol. 3, no. 1, pp. 45-53, 2014.

[6] A. Zulkarnain, "PENGGUNAAN DESAIN GRAFIS PADA MAJALAH HIDAYATULLAH SEBAGAI MEDIA DAKWAH DALAM MENARIK MINAT BACA MAD’U DI BANDAR LAMPUNG,” 2018.

[7] A. P. Musmuliadi, "Pengaruh Media Desain Grafis Berbasis Adobe," J. Teknol. Pendidik., vol. 3, no. April, 2018.

[8] A. Jornet and W. M. Roth, "Imagining design: Transitive and intransitive dimensions," Des. Stud., vol. 56, pp. 28-53, 2018, doi: 10.1016/j.destud.2018.02.002.

[9] A. A. Gunawan, "Preliminary Study of Classifying Indonesian Entrepreneurs," Procedia - Soc. Behav. Sci., vol. 115, no. Iicies 2013, pp. 243-250, 2014, doi: 10.1016/j.sbspro.2014.02.432.

[10] S. Sawqy, "Pengaruh Kepribadian Terhadap Intensi Berwirausaha Mahasiswa Jurusan Desain Grafis Dan Multimedia Universitas Mercu Buana Jakarta,” 2010.

[11] D. I. E. Sundah, C. Langi, D. R. S. Maramis, and L. Dan Tawalujan, "Developing entrepreneurial competencies for successful business model canvas," J. Phys. Conf. Ser., 
vol. 953, no. 1, pp. 0-23, 2018, doi: 10.1088/1742-6596/953/1/012040.

[12] N. K. Indrawati, U. Salim, Djumahir, and A. H. Djawahir, "Moderation Effects of Entrepreneurial Self-efficacy in Relation between Environmental Dimensions and Entrepreneurial Alertness and the Effect on Entrepreneurial Commitment," Procedia Soc. Behav. Sci., vol. 169, no. August 2014, pp. 13-22, 2015, doi: 10.1016/j.sbspro.2015.01.281.

[13] Romadecade, "Pengertian Wirausahawan," romadecade.org, 2019. .

[14] Bisnisukm, "Sukes Menjadi Pengusaha Melalui Desain Grafis," bisnisukm.com, 2018. .

[15] Investasiuntung, "12 Cara Membuka Usaha Desain Grafis Untung Jutaan," investasiuntung.com, 2017. .

[16] P. Pujiyanto, "Jiwa Entrepreneurship Penggerak Desain," ANDHARUPA J. Desain Komun. Vis. Multimed., vol. 4, no. 02, pp. 239-251, 2018, doi: 10.33633/andharupa.v4i02.1966.

[17] P. C. Hastuti, A. Thoyib, E. A. Troena, and M. Setiawan, "The Minang Entrepreneur Characteristic," Procedia - Soc. Behav. Sci., vol. 211, no. September, pp. 819-826, 2015, doi: 10.1016/j.sbspro.2015.11.108.

[18] W. Walipah and N. Naim, "Faktor - Faktor Yang Mempengaruhi Niat Berwirausaha Mahasiswa," J. Ekon. Mod., vol. 12, no. 3, p. 138, 2016, doi: 10.21067/jem.v12i3.1461.

[19] M. Suyatno and et al, Aplikasi desain grafis untuk periklanan. Andi Yogyakarta, 2004.

[20] Suryana, Kewirausahaan Pedoman Praktis: Kiat dan Proses Menuju Sukses. Jakarta: Salemba Karya, 2008.

[21] Google, "Definisi Populasi Penelitian," Google, 2016. .

[22] M. P. Dr. Whidmurni, "Penelitian Kuantitatif," Pemaparan Metod. Kuantitatif, 2017.

[23] I. Agusta, "Teknik Pengumpulan dan Analisis Data Kualitatif," J. Stud. Komun. dan Media, vol. 02, no. 1998, pp. 1-11, 2014.

[24] P. D. Sugiyono, metode penelitian kuantitatif, kualitatif,dan R\&D. 2016.

[25] Sugiyono, "Metode Penelitian Kombinasi (Mixed Methods)," Bandung Alf., 2010, doi: 10.1016/S0969-4765(04)00066-9.

[26] A. Field, Discovering statistics using IBM SPSS statistics. 2013.

[27] A. D. . Janie, "Statistik Deskripstif dan Regresi Linier Berganda dengan SPSS," in Statistik Deskripstif dan Regresi Linier Berganda dengan SPSS, 2012.

[28] V. W. Sujarweni, SPSS Untuk Penelitian, 1st ed. Yogyakarta: Pustaka Baru Press, 2015.

[29] F. Yusup, "Uji Validitas dan Reliabilitas Instrumen Penelitian Kuantitatif," J. Tarb. J. Ilm. Kependidikan, 2018, doi: 10.18592/tarbiyah.v7i1.2100.

[30] D. Panentu and M. Irfan, "Uji Validitas Dan Reliabilitas Butir Pemeriksaan Dengan Moteral Cognitive Assessment Versi Indonesia ( MoCA- INA ) Pada Insan Pasca Stroke Fase Recovery," J. Fisioter., 2013. 
[31] D. Damanik and F. S. Wibowo, "Implementasi Strategi 4P Dalam Meningkatkan Frekuensi Public Event Di Harris Hotel and Conventions Bekasi (Hhcb)," Natl. Conf. Creat. Ind., no. September, pp. 5-6, 2018, doi: 10.30813/ncci.v0i0.1248. 